\title{
PENALARAN MATEMATIS SISWA DALAM PEMECAHAN MASALAH ALJABAR DITINJAU DARI GAYA KOGNITIF FIELD DEPENDENT - FIELD INDEPENDENT
}

\author{
Sherly Mayfana Panglipur Yekti ${ }^{1}$, Tri Atmojo Kusmayadi ${ }^{2}$ Riyadi $^{3}$ \\ ${ }^{1,2,3}$ Prodi Magister Pendidikan Matematika, FKIP Universitas Sebelas Maret Surakarta
}

\begin{abstract}
The research aims to describe the mathematical reasoning of students with Field Dependent (FI) and Field Independent (FD) cognitive style in solving algebra problems. Type of this research is descriptive qualitative. The cognitive styles of 32 students of class VIII H SMPN 2 Karanganyar were determined using Group Embedded Figures Test (GEFT). Each category of cognitive styles was taken three students with the high, medium, and low scores and were used as research subjects. Data was collected by interview based tasks. Validity of the data used time triangulation. Techniques of data analysis were done by: (1) classfying the data into Polya's problem solving steps, (2) presenting the data in narrative text, and (3) concluding the students' mathematical reasoning in each Polya's problem solving steps. The results of this research showed that mathematical reasoning students with FD cognitive styles in algebra problem solving is: (1) able to identify the problem clearly and completely, (2) able to describe the conditions of the problem, (3) able to connect different elements of information but not perfect. While the mathematical reasoning students with FI cognitive styles in algebra problem solving is: (1) able to identify the problem clearly and completely, (2) able to describe the conditions of the problem, (3) able to connect different elements of information completely, (4) able to apply algebraic concepts that have been studied previously, and (5) able to make conjectures for problem solving strategies but incomplete.

Keywords: Mathematical reasoning, algebra problems, cognitive styles
\end{abstract}

\section{PENDAHULUAN}

Indikator mengenai kemampuan peserta didik Indonesia di bidang matematika salah satunya dapat dilihat dari hasil studi Trends in International Mathematics and Science Study (TIMSS). TIMSS adalah studi internasional untuk mengevaluasi pendidikan, khususnya untuk hasil belajar peserta didik yang berusia 14 tahun pada jenjang sekolah menengah pertama (SMP). TIMSS dirancang untuk meneliti pengetahuan dan kemampuan matematika dan sains anak-anak berusia 14 tahun beserta informasi yang berasal dari peserta didik, guru, dan kepala sekolah.

Penelitian yang dilakukan Rosnawati (2013) mengungkap bahwa capaian ratarata peserta Indonesia pada TIMSS relatif rendah. Hasil penelitian menunjukkan bahwa kemampuan rata-rata peserta didik Indonesia pada tiap domain konten maupun kognitif pada hasil TIMSS masih jauh di bawah negara tetangga Malaysia, Thailand, dan Singapura. Pada TIMSS 2011 Indonesia menempati urutan ke 38 dari 42 negara peserta. Rata-rata persentase yang paling rendah yang dicapai oleh peserta didik Indonesia pada domain kognitif pada level penalaran yaitu 17\%. Selain itu penelitian Sulistiawati (2014) juga menunjukkan bahwa persentase siswa SMP yang mampu menjawab soal-soal penalaran matematis dengan benar hanya sebesar $14,29 \%$. 
Dijelaskan dalam penelitian Amrina Rizta dkk (2013) bahwa salah satu faktor penyebab rendahnya penalaran siswa karena soal-soal yang diberikan guru dalam pembelajaran matematika lebih menekankan ke pemahaman konsep, sedangkan soal-soal yang menuntut kemampuan berpikir tingkat tinggi termasuk bernalar secara matematis jarang dilatihkan. Hal tersebut diperkuat oleh penelitian Herman (dalam Sulistiawati, 2014: 205) yang menyatakan bahwa dalam kegiatan pembelajaran kebanyakan guru matematika berkonsentrasi mengejar skor Ujian Nasional (UN) setinggi mungkin. Oleh karena itu kegiatan pembelajaran biasanya difokuskan untuk melatih siswa terampil menjawab soal matematika, sehingga penalaran matematis siswa kurang berkembang. Penelitian yang dilakukan Iryanti (dalam Amrina Rizta dkk, 2013:81) menunjukkan bahwa sebesar $57 \%$ persentase waktu pembelajaran matematika di Indonesia lebih banyak digunakan untuk membahas soal-soal dengan kompleksitas rendah, dan hanya sekitar 3\% waktu yang digunakan untuk membahas soal-soal dengan kompleksitas tinggi.

Terdapat beragam pengertian mengenai penalaran matematis menurut para ahli, namun pada prinsipnya pengertian tersebut relatif sama. English (2004:13) menjelaskan bahwa yang dimaksud penalaran matematis adalah suatu kegiatan yang berupa perhitungan, mengumpukan fakta-fakta, menganalisis data, memperkirakan, menjelaskan, dan membuat suatu kesimpulan. Menurut NCTM (2009:9) secara umum terdapat beberapa tahapan dalam penalaran matematis yaitu: (a) menganalisis masalah, (b) menerapkan strategi, (c) mencari dan menggunakan hubungan antara domain matematika yang berbeda, konteks yang berbeda, dan representasi berbeda, (d) merefleksikan solusi pada suatu masalah.

Selanjutnya mengenai pentingnya peran penalaran matematis dalam matematika dikemukakan oleh Loong et al (2014: 466) yang menyatakan bahwa penalaran matematis adalah kemampuan yang dijadikan pondasi dalam berpikir matematis. Polya (dalam Nunes et al, 2012) juga menambahkan bahwa kemampuan penalaran berperan penting dalam kesuksesan belajar matematika. Salah satu peran penting penalaran matematis dalam matematika adalah untuk mengembangkan keterampilan siswa dalam memecahkan masalah. Dengan kebiasaan bernalar secara matematis yang baik, siswa akan mampu memahami dan menggunakan apa yang telah mereka pelajari di sekolah untuk menyelesaikan masalah secara efektif.

Menurut Dewey (dalam Bilgin dan Karakirik, 2005) masalah adalah apa yang harus dilakukan seseorang ketika orang tersebut tidak mengetahui apa yang harus dilakukan. Tidak setiap soal dapat disebut masalah. Hudoyo (dalam ArisYuwono, 2010:34) menyatakan bahwa sesuatu disebut masalah bagi siswa jika: a) pertanyaan yang dihadapkan kepada siswa harus dapat dimengerti oleh siswa tersebut, namun pertanyaan 
itu harus merupakan tantangan baginya untuk menjawab, dan b) pertanyaan tersebut tidak dapat dijawab dengan prosedur rutin yang telah diketahui siswa.

Bagian dari matematika yang sering menjadi masalah adalah aljabar. Menurut Samo (2009) aljabar merupakan bagian penting dari matematika yang digunakan untuk menggeneralisasi aritmetika melalui simbol, huruf, dan tanda-tanda tertentu. Penggunaan simbol, huruf, dan tanda-tanda tersebut menjadikan aljabar sebagai ilmu yang abstrak. Lee dan Wheeler (1989) menyatakan bahwa keabstrakan dari aljabar adalah salah satu alasan untuk kesulitan para siswa. Agar terampil memecahkan masalah khususnya terkait masalah aljabar, siswa membutuhkan banyak kesempatan untuk melatih dan mengasah kemampuannya dalam memecahkan masalah. Hal tersebut dapat dirancang guru sebagai fasilitator dalam pembelajaran dengan memberikan soal atau masalah-masalah aljabar yang bersifat kontekstual.

Untuk memperoleh suatu solusi dari masalah, siswa perlu menganalisis masalah yang ada kemudian menyesuaikannya dengan informasi yang pernah diberikan selama pembelajaran. Masing-masing siswa tentu akan berbeda dalam menyusun dan mengolah informasi yang mereka dapatkan. Perbedaan antar siswa dalam menyusun dan mengolah informasi salah satunya dikarenakan perbedaan gaya kognitif yang dimilikinya. Gaya kognitif merupakan kecenderungan seseorang dalam menyusun dan mengolah suatu informasi. Woolfolk (dalam Hamzah Uno, 2010:186) menunjukkan bahwa di dalam gaya kognitif terdapat suatu cara yang berbeda untuk melihat, mengenal, dan mengorganisasi informasi. Setiap individu akan memilih cara yang disukai dalam memproses dan mengorganisasi informasi sebagai respons terhadap stimuli lingkungannya.

Pithers (2002) mendefinisikan gaya kognitif sebagai strategi yang relatif stabil, pilihan dan sikap yang menunjukkan tipe atau kecenderungan seseorang dalam merasakan, mengingat, dan memecahkan masalah. Witkin (dalam O'Brien et al, 2001) menyatakan terdapat beberapa dimensi gaya kognitif, salah satunya adalah gaya kognitif Field Dependent dan Field Independent. Gaya kognitif Field Dependent dan Field Independent mencerminkan cara analisis seseorang dalam berinteraksi dengan lingkungan. Beberapa penelitian mengenai gaya kognitif Field Dependent dan Field Independent dan interaksinya telah dilakukan.

Almolhodaei (2002) melakukan penelitian mengenai hubungan antara gaya kognitif siswa dengan kemampuannya dalam memecahkan masalah matematika. Hasil penelitian menunjukkan bahwa cara berpikir siswa Field Independent yang cenderung analitik dapat mendukung performa dalam memecahkan masalah matematika lebih baik dibanding siswa dengan gaya kognitif Field Dependent yang cara berpikirnya cenderung global. Penelitian lain dilakukan Onyekuru (2015) terkait hubungan antara gaya kognitif 
Field Independent-Field Dependent dan gender, pilihan karir, dan prestasi akademik. Hasil yang diperoleh menunjukkan proporsi siswa laki-laki FI lebih tinggi dibanding proporsi siswa perempuan FI. Kemudian diketahui siswa dengan gaya kognitif FI lebih unggul dalam prestasi sains dibandingkan siswa dengan gaya kognitif FD. Sedangkan siswa dengan gaya kognitif FD lebih unggul dalam prestasi seni dibandingkan siswa dengan gaya kognitif FI.

Berdasarkan uraian di atas maka tujuan dari penelitian ini adalah untuk mendeskripsikan penalaran matematis siswa dengan gaya kognitif Field Dependent dan siswa dengan gaya kognitif Field Independent dalam pemecahan masalah aljabar.

\section{METODE PENELITIAN}

Jenis penelitian yang digunakan pada penelitian ini adalah kualitatif dengan desain studi kasus. Penelitian ini dilaksanakan di SMP Negeri 2 Karanganyar pada semester ganjil tahun pelajaran 2015/ 2016, yang melalui beberapa tahapan yaitu: tahap persiapan penelitian, tahap pengumpulan dan analisis data, serta tahap penyusunan laporan.

Pada tahap persiapan dilakukan kegiatan sebagai berikut: (1) mengkaji teori tentang penalaran matematis siswa kaitannya dengan pemecahan masalah aljabar, dan juga kajian tentang gaya kognitif yang dikaitkan dengan pemecahan masalah. Hasil kajian teori memunculkan rasa ingin tahu peneliti tentang penalaran matematis siswa kelas VIII SMP dalam pemecahan masalah aljabar ditinjau dari gaya kognitif Field Dependent Field Independent. (2) Melakukan pra-penelitian untuk memperoleh gambaran di lapangan tentang kemampuan penalaran matematis siswa, kemudian dibandingkan dengan kajian teori sehingga kegiatan ini mendorong peneliti mengajukan masalah penelitian. (3) Untuk menjawab permasalahan peneliti melakukan penelitian kualitatif desain studi kasus. Penelitian ini bertujuan mendeskripsikan penalaran matematis siswa kelas VIII SMP Negeri 2 Karanganyar yang mempunyai gaya kognitif Field Dependent (FD) dan Field Independent (FI) dalam pemecahan masalah aljabar. Sebagai alat pengumpulan data, peneliti menyusun draf instrumen bantu berupa tes tertulis pemecahan masalah aljabar dan pedoman wawancara, sedangkan untuk memperoleh kategori gaya kognitif FI dan FD melalui tes Group Embedded Figures Test (GEFT). (4) Untuk mendapatkan instrumen bantu yang valid, peneliti memvalidasikan instrumen bantu yang digunakan kepada validator yang kompeten di bidangnya. (5) Setelah semua instrumen bantu valid peneliti mengajukan ijin penelitian pada sekolah tujuan untuk kelancaran penelitian. 
Pada tahap pengumpulan dan analisis data dilakukan kegiatan sebagai berikut: (1) memilih subjek penelitian yang memenuhi kriteria pemilihan subjek pada siswa kelas VIII SMP untuk menyelesaikan tes pemecahan masalah aljabar pertama. (2) Peneliti menganalisis hasil tes tertulis subjek kemudian melakukan wawancara pertama dengan subjek untuk mengklarifikasi jawaban yang diberikan. Berdasar hasil analisis ini diperoleh data subjek penelitian untuk wawancara berbasis tugas pertama. Selang beberapa hari, peneliti memberikan tes pemecahan masalah aljabar kedua yang setipe dengan tes pemecahan masalah aljabar pertama, kepada subjek yang sama. Hasil tes tertulis pemecahan masalah kedua ini dianalisis dan kemudian dilakukan wawancara kedua dengan subjek untuk mengklarifikasi jawaban yang diberikan. Berdasar hasil analisis ini diperoleh data subjek penelitian untuk wawancara berbasis tugas kedua. (3) Selanjutnya dilakukan triangulasi waktu dengan cara membandingkan hasil analisis data wawancara berbasis tugas pertama dan kedua. Jika tidak terdapat perbedaan signifikan antara data pertama dan kedua, maka dikatakan data tersebut valid. Data valid kemudian dianalisis kembali secara lebih mendalam untuk memperoleh kesimpulan tentang penalaran matematis siswa dalam pemecahan masalah aljabar ditinjau dari gaya kognitif Field Dependent - Field Independent.

Subjek dalam penelitian ini adalah siswa kelas VIII H SMP Negeri 2 Karanganyar Tahun Pelajaran 2015/2016. Teknik pemilihan subjek menggunakan metode purposive sampling. Kriteria pemilihan subjek penelitian ini yaitu: (1) telah memperoleh pembelajaran materi aljabar, (2) berada pada kategori gaya kognitif yang akan diteliti yaitu Field Dependent atau Field Independent, (3) mampu mengomunikasikan pemikirannya secara lisan maupun tertulis dengan baik.

Penentuan subjek yang dibagi menjadi dua kategori gaya kognitif yaitu Field Dependent dan Field Independent tersebut diperoleh berdasarkan hasil tes gaya kognitif Group Embedded Figures Test (GEFT). Selanjutnya pada tiap kategori gaya kognitif diambil masing-masing 3 subjek dengan skor perolehan tinggi, sedang, rendah sehingga pada penelitian ini diperoleh sebanyak 6 subjek penelitian. Data dan sumber data dapat diperoleh dari hasil tes tertulis dan wawancara subjek. Teknik pengumpulan data dilakukan langsung oleh peneliti sebagai instrumen utama, dan juga melalui tes pemecahan masalah aljabar sebagai instrumen bantu pertama dan pedoman wawancara sebagai instrumen bantu kedua.

Proses pengumpulan data dimulai dengan memberikan tes pemecahan masalah aljabar pertama pada subjek penelitian dan melakukan wawancara pertama. Data hasil wawancara berbasis tugas pertama selanjutnya dianalisis. Selang beberapa hari, diberikan tes pemecahan masalah aljabar kedua yang setipe dengan tes pemecahan masalah aljabar 
pertama, kepada subjek yang sama. Data hasil wawancara berbasis tugas kedua juga dianalisis. Setelah itu dilakukan triangulasi waktu dengan membandingkan data pertama dan kedua untuk memperoleh data valid. Data yang valid kemudian digunakan untuk mengetahui penalaran matematis subjek.

Analisis data dalam penelitian ini merupakan proses mencari dan menyusun serta mendeskripsikan secara sistematis data yang diperoleh dari hasil wawancara berbasis tugas pertama dan hasil wawancara berbasis tugas kedua dengan cara mereduksi data, menyajikan data, dan menarik kesimpulan (Miles dan Huberman dalam Sugiyono, 2013). Hasil ini kemudian dijadikan sebagai deskripsi penalaran matematis siswa kelas VIII SMP dalam pemecahan masalah aljabar yang ditinjau dari gaya kognitif Field Dependent - Field Independent.

\section{HASIL PENELITIAN DAN PEMBAHASAN}

\section{Subjek dengan gaya kognitif Field Independent}

Dari hasil analisis data ketiga subjek dengan gaya kognitif Field Independent yaitu AF, LSF, dan AON diperoleh data penalaran matematis siswa dengan gaya kognitif Field Independent. Hasil dari analisis data menunjukkan bahwa penalaran matematis yang digunakan siswa dalam pemecahan masalah aljabar cukup beragam. Meskipun ketiga subjek memiliki gaya kognitif yang sama, namun cara mereka menyelesaikan masalah belum tentu sama. Pada tahap memahami masalah subjek AF, LSF, maupun AON mampu mengidentifikasi masalah dengan menuliskan informasi yang diperoleh dari soal dengan jelas dan lengkap. Selain itu mereka juga mampu menggambarkan kondisi dari masalah dengan menggunakan gambar secara jelas dan lengkap serta memahami dengan baik maksud dari soal tersebut.

Pada tahap pemecahan masalah yang kedua yaitu menyusun rencana, subjek AF menunjukkan performa tertinggi. Subjek AF mampu menghubungkan elemen-elemen yang berbeda dari informasi yang diperoleh dengan menggunakan bentuk aljabar. Selain itu subjek mampu menerapkan konsep yang telah dipelajari sebelumnya ataupun pengetahuan yang dimiliki untuk menyelesaikan masalah. Dari hasil analisis data subjek AF mampu menerapkan menerapkan manipulasi aljabar, operasi aljabar, operasi bilangan, sifat dan luas bangun datar serta pemfaktoran bentuk aljabar dengan baik.

Subjek LSF pada tahap menyusun rencana juga menunjukkan performa yang tidak jauh berbeda dari subjek AF. Subjek LSF mampu menghubungkan elemen-elemen yang berbeda dari informasi yang diperoleh dengan menggunakan bentuk aljabar dan juga menerapkan konsep yang telah dipelajari sebelumnya ataupun pengetahuan yang dimiliki untuk menyelesaikan masalah. Namun yang menjadi perbedaan adalah subjek 
LSF mengalami kendala/ kesulitan pada saat menerapkan konsep pemfaktoran bentuk aljabar. Subjek tidak tepat dalam menentukan hasil pemfaktoran. Ketidaktepatan subjek LSF dalam menentukan hasil pemfaktoran nantinya akan berpengaruh ke langkahlangkah selanjutnya.

Untuk selanjutnya adalah subjek AON. Subjek dengan kategori gaya kognitif FIR ini menunjukkan performa yang sedikit lebih rendah dibanding AF dan LSF dalam tahap menyusun rencana. Subjek AON mampu menghubungkan elemen-elemen yang berbeda dari informasi yang diperoleh dengan menggunakan bentuk aljabar. Namun dalam menerapkan konsep yang telah dipelajari sebelumnya ataupun pengetahuan yang dimiliki untuk menyelesaikan masalah, subjek AON mengalami kendala di tiga konsep yaitu manipulasi aljabar, operasi aljabar, dan pemfaktoran bentuk aljabar. Indikator penalaran matematis ketiga pada tahap menyusun rencana penyelesaian yaitu mampu mengajukan dugaan strategi pemecahan masalah secara lengkap dan tepat. Ketiga subjek dengan gaya kognitif Field Independent yaitu AF, LSF, dan AON mampu memenuhi indikator penalaran matematis tersebut.

Tahap ketiga dari pemecahan masalah aljabar adalah melaksanakan rencana penyelesaian. Tahap ini memuat tiga indikator penalaran matematis yaitu: (1) menguji dugaan-dugaan, (2) menyusun bukti, dan (3) memberikan alasan terhadap suatu solusi. Dari hasil analisis subjek AF mampu memenuhi ketiga indikator tersebut dengan baik dan sempurna. Sedangkan subjek LSF hanya mampu memenuhi indikator pertama. Pada indikator kedua yaitu menyusun bukti, sebenarnya subjek LSF secara umum sudah mampu menyusun bukti hanya saja belum sempurna. Hal tersebut karena subjek keliru dalam menghitung solusi dari keliling bangun persegi. Kesalahan tersebut karena subjek kurang menguasai/ menerapkan konsep pemfaktoran aljabar dengan baik. Akibatnya subjek salah dalam menentukan nilai hasil pemfaktoran yang digunakan. Kesalahan itu pula yang kemudian menyebabkan subjek LSF tidak memenuhi indikator penalaran matematis yang ketiga dengan sempurna. Subjek LSF secara umum sudah mampu memberikan alasan logis terhadap langkah penyelesaian dan solusi yang diperoleh. Hanya saja pada saat memberikan alasan pemilihan hasil dari pemfaktoran yang digunakan subjek keliru.

Selanjutnya yaitu subjek AON. Dari ketiga indikator penalaran matematis di atas subjek AON belum mampu memenuhi ketiganya. Subjek sudah menguji dugaan dengan mengerjakan soal sesuai dengan langkah-langkah penyelesaian yang telah disusun sebelumnya. Subjek juga sudah menggunakan hubungan yang telah dibuat untuk mencapai solusi, namun belum tepat. Karena subjek belum mampu menguji dugaan dengan tepat, maka pada langkah menyusun bukti yang dikerjakan subjek AON pun 
menjadi kurang tepat. Hal ini karena antara indikator pertama, kedua, dan ketiga saling berkaitan. Kesalahan subjek pada indikator pertama otomatis akan mempengaruhi hasil penyelesaian pada indikator kedua dan ketiga. Tahap terakhir dalam pemecahan masalah adalah memeriksa kembali. Indikator penalaran matematis dalam tahap ini adalah menarik kesimpulan. Dari ketiga subjek, hanya subjek AF yang mampu menarik kesimpulan dengan tepat. Sedangkan untuk subjek LSF dan AON sebenarnya sudah melakukan proses menarik kesimpulan juga, namun karena solusinya kurang tepat maka kesimpulan yang diperoleh pun menjadi kurang tepat. Uraian mengenai keberagaman penalaran matematis siswa yang digunakan dalam pemecahan masalah aljabar tersebut sesuai dengan pernyataan Hamzah Uno (2010) yang menyatakan bahwa karakteristik individu yang memiliki gaya kognitif sama belum tentu memiliki kemampuan yang sama.

Selanjutnya berdasarkan keseluruhan hasil analisis ketiga subjek tersebut diperoleh deskripsi penalaran matematis siswa dengan gaya kognitif Field Independent secara umum yaitu (1) mampu mengidentifikasi masalah dengan menuliskan informasi yang diperoleh dari soal dengan jelas dan lengkap, (2) mampu menggambarkan kondisi dari masalah dengan mengilustrasikannya dalam bentuk gambar secara jelas dan lengkap serta memahami dengan baik maksud dari soal tersebut. (3) Mampu menghubungkan elemen-elemen yang berbeda dari informasi yang diperoleh dengan menggunakan bentuk aljabar dengan tepat, (4) mampu menerapkan konsep aljabar yang telah dipelajari sebelumnya untuk membuat pengetahuan baru yang berguna dalam pencapaian solusi dan mampu menerapkan manipulasi aljabar, operasi aljabar, operasi bilangan, sifat dan luas bangun datar serta pemfaktoran bentuk aljabar dengan baik, dan (5) mampu mengajukan dugaan strategi pemecahan masalah namun belum lengkap.

Temuan lain pada penelitian ini adalah bahwa pada siswa Field Independent dengan skor tinggi, selain mampu memenuhi kelima indikator yang disebutkan di atas, subjek juga mampu memenuhi indikator penalaran matematis lainnya yaitu mampu menguji dugaan sesuai dengan strategi pemecahan masalah yang telah disusun dengan tepat dan menggunakan hubungan-hubungan yang telah dibuat untuk mencapai solusi, mampu menyusun bukti terhadap solusi yang diperoleh dengan menuliskan proses perhitungan secara sistematis, lengkap, dan jelas sehingga menghasilkan solusi yang tepat, mampu memberikan alasan logis terhadap solusi yang diperoleh, dan mampu menarik kesimpulan dengan tepat. Temuan tersebut sesuai dengan penelitian (Witkin et $a l$, 1977) yang menyatakan bahwa siswa dengan skor tinggi dalam GEFT secara umum lebih sukses menyelesaikan masalah dibandingkan siswa dengan skor yang lebih rendah.

\section{Subjek dengan gaya kognitif Field Dependent}


Dari hasil analisis data subjek CZB, MRK, dan NR diperoleh data penalaran matematis siswa dengan gaya kognitif Field Dependent. Tahap pertama dalam pemecahan masalah aljabar adalah memahami masalah. Indikator penalaran matematis pada tahap ini ada dua yaitu: (1) mengidentifikasi masalah dan (2) menggambarkan kondisi dari masalah. Dari hasil analisis tampak ketiga subjek yaitu CZB, MRK, dan NR mampu memenuhi indikator penalaran matematis pertama dengan baik. Selanjutnya pada indikator kedua, ketiganya memunculkan respon yang sama yaitu mampu menggambarkan kondisi dari masalah namun kurang memahami maksud dari soal tersebut. Subjek CZB dan MRK menggambarkan kondisi dari masalah dengan menggunakan gambar, sedangkan subjek NR menggambarkan kondisi dari masalah menggunakan simbol/ variabel.

Kurangnya pemahaman siswa terhadap soal yang dimaksud adalah karena subjek dengan gaya kognitif Field Dependent cenderung mempersepsi pola atau informasi sebagai suatu keseluruhan. Hal ini sesuai dengan pernyataan Witkin dalam Dimyati Mahmud (2009) yang menyatakan bahwa orang yang memiliki gaya kognitif Field Dependent cenderung mempersepsi suatu pola sebagai keseluruhan. Sulit baginya untuk memusatkan pada satu aspek situasi. Tahap kedua dalam pemecahan masalah aljabar adalah menyusun rencana penyelesaian. Indikator penalaran matematis pada tahap ini ada tiiga yaitu: (1) menghubungkan elemen-elemen yang berbeda dari informasi yang diperoleh dengan menggunakan bentuk aljabar, (2) menerapkan konsep yang telah dipelajari sebelumnya (pengetahuan yang dimiliki) dalam situasi permasalahan baru, dan (3) mengajukan dugaan-dugaan.

Subjek CZB mencoba menghubungkan elemen-elemen yang berbeda dari informasi yang diperoleh dengan menggunakan bentuk aljabar, namun hubungan yang diperoleh kurang tepat. Hal tersebut karena subjek kurang memahami dengan baik informasi pada soal. Subjek keliru dalam menggunakan tanda penjumlahan dan pengurangan. Subjek MRK membuat hubungan antara informasi yang diperoleh dalam bentuk aljabar, namun hubungan yang diperoleh kurang tepat. Hal tersebut karena subjek kurang memahami dengan baik informasi dari soal. Subjek juga kesulitan dalam merubah konteks dari soal kontekstual ke dalam bentuk matematika. Subjek NR membuat hubungan antara informasi yang diperoleh dalam bentuk pertidaksamaan aljabar, namun hubungan yang diperoleh kurang tepat. Subjek salah dalam menggunakan notasi pertidaksamaan.

Untuk indikator kedua, subjek MRK tampak belum mampu menerapkan konsep variabel dan manipulasi aljabar dengan baik. Hal tersebut ditunjukkan dengan ketidakkonsistenan subjek dalam menggunakan variabel dan memisalkan kuantitas yang 
nilainya sudah jelas ke dalam variabel. Sedangkan subjek CZB dan NR tampak belum mampu menerapkan konsep aljabar dengan baik. Hal tersebut ditunjukkan dengan melakukan kesalahan dalam membuat hubungan dan memilih strategi penyelesaian. Indikator ketiga adalah mengajukan dugaan-dugaan. Karena subjek CZB dan NR belum mampu menerapkan konsep aljabar dengan baik, maka secara otomatis juga belum mampu mengajukan dugaan penyelesaian masalah dengan tepat. Subjek MRK mengajukan dugaan namun belum sempurna. Hal tersebut karena dari tiga langkah penyelesaian yang disebutkan, satu diantaranya keliru. Tahap ketiga dalam pemecahan masalah aljabar adalah melaksanakan rencana penyelesaian. Indikator penalaran matematis pada tahap ini ada tiga yaitu: (1) menguji dugaan-dugaan, (2) menyusun bukti, dan (3) memberikan alasan terhadap suatu solusi.

Indikator pertama yaitu menguji dugaan. Subjek CZB, MRK, dan NR menguji dugaan sesuai dengan strategi pemecahan masalah yang telah disusun namun tidak menggunakan hubungan-hubungan yang telah dibuat untuk mencapai solusi. Karena pada tahap menyusun rencana penyelesaian, subjek memilih strategi pemecahan yang kurang tepat, maka dampaknya adalah subjek juga salah dalam menguji dugaan-dugaan yang dimunculkan. Selanjutnya untuk indikator kedua dan ketiga. Indikator kedua dan ketiga berkaitan erat dengan indikator pertama. Subjek CZB dan MRK tidak menggunakan hubungan-hubungan yang telah dibuat untuk mencapai solusi. Subjek menggunakan informasi pada soal tanpa pengembangan. Tampak subjek tidak menggali pemecahan masalah lebih jauh. Subjek NR juga belum mampu menyusun bukti dengan baik. Hal tersebut dikarenakan subjek NR belum mampu menerapkan konsep yang pernah dipelajarinya dengan baik.

Kemudian untuk indikator penalaran matematis ketiga, subjek CZB, MRK, dan NR belum mampu memberikan alasan logis terhadap solusi yang diperoleh. Hal ini dikarenakan ketiga subjek belum mampu memenuhi indikator penalaran matematis pertama dan kedua. Selanjutnya tahap terakhir dalam pemecahan masalah adalah memeriksa kembali. Indikator penalaran matematis dalam tahap ini adalah menarik kesimpulan. Pada tahap ini tidak ada subjek gaya kognitif Field Dependent yang menarik kesimpulan dengan tepat. Sebenarnya langkah yang dilakukan siswa untuk menarik kesimpulan sudah tepat, hanya saja karena solusi yang diperoleh belum tepat sehingga kesimpulannya pun menjadi kurang tepat.

\section{Perbedaan Penalaran Matematis dalam Pemecahan Masalah Aljabar antara subjek Field Dependent dengan subjek Field Independent}

Berdasarkan analisis data yang telah dilakukan, terlihat bahwa penalaran matematis yang digunakan dalam pemecahan masalah antara subjek gaya kognitif Field 
Dependent dan subjek dengan gaya kognitif Field Independent berbeda. Hal ini sejalan dengan penelitian Woolfolk (dalam Hamzah Uno, 2010) yang menyatakan bahwa di dalam gaya kognitif terdapat suatu cara yang berbeda untuk melihat, mengenal, dan mengorganisasi suatu informasi. Dalam menuliskan informasi yang diperoleh, kecenderungan siswa dengan gaya kognitif Field Dependent hanya menuliskan beberapa informasi yang diperoleh, sedangkan siswa dengan gaya kognitif Field Independent menuliskan secara lengkap informasi yang diperoleh. Hal ini sesuai dengan ciri-ciri siswa gaya kognitif Field Dependent- Field Independent yang disebutkan oleh Witkin (dalam Desmita, 2009) yaitu bahwa siswa dengan gaya kognitif Field Dependent memerlukan instruksi yang jelas dan bimbingan dalam memecahkan masalah, sedangkan siswa dengan gaya kognitif Field Independent lebih mampu memecahkan masalah tanpa instruksi dan bimbingan.

Selanjutnya dalam menggambarkan kondisi dari masalah. Subjek dengan gaya kognitif Field Dependent agak sulit menggambarkan kondisi masalah dalam bentuk matematika, sedangkan siswa dengan gaya kognitif Field Independent menggambarkan masalah secara detail dalam bentuk matematika. Hal tersebut sesuai dengan penelitian (Witkin dan Goodenough, 1976), dan (Saracho, 1988) yang menyatakan bahwa siswa dengan gaya kognitif Field Dependent cenderung mempersepsi pola sebagai suatu keseluruhan, sedangkan siswa dengan gaya kognitif Field Independent cenderung mempersepsi bagian-bagian yang terpisah dari suatu pola menurut komponenkomponennya.

Subjek gaya kognitif Field Independent lebih cepat memahami maksud dari soal dibandingkan dengan subjek gaya kognitif Field Dependent. Hal ini sesuai dengan penelitian Alamolhodaei (2002) yang menyatakan bahwa cara berpikir siswa Field Independent lebih tinggi daripada siswa Field Dependent. Penelitian oleh Witkin (dalam Desmita, 2009) juga menyebutkan bahwa siswa FI cenderung analitis dalam berpikir, sedangkan siswa FD memandang pola sebagai keseluruhan. Hal tersebut juga menjelaskan mengapa siswa FI lebih mampu membuat hubungan antara informasiinformasi yang diketahui untuk memperoleh pengetahuan baru yang berguna dalam mecapai solusi. Sedangkan siswa FD cenderung tidak berusaha untuk menggali pengetahuan baru dari informasi-informasi yang diperoleh.

Baik siswa FI maupun siswa FD memiliki kendala masing-masing dalam menerapkan konsep yang telah dipelajari sebelumnya. Namun kendala yang muncul pada siswa FD lebih banyak dibandingkan siswa FI. Hal ini sesuai dengan penelitian Spitler (dalam Almolhodaei, 2002), Loren (dalam Panah, 2010) yang menyatakan bahwa secara konseptual, performa matematika siswa FI memiliki tingkat efisiensi lebih tinggi 
dibandingkan siswa FD. Dalam mengajukan dugaan, siswa FI dan FD sama-sama menggunakan strategi pemecahan yang dianggap paling sesuai. Yang sedikit berbeda adalah siswa FD cenderung menggunakan langkah-langkah pemecahan yang telah diketahui sebelumnya, misalnya dari yang pernah dicontohkan guru. Sedangkan siswa FI, menggunakan langkah pemecahan masalah yang disesuaikan dengan informasi yang diketahui dan hubungan yang dibuat. Hal ini sejalan dengan penelitian Nasution (2000), Nur Ghufron dan Rini Risnawati (2012) yang menyatakan bahwa siswa FD sangat dipengaruhi lingkungannya, sedangkan siswa FI kurang dipengaruhi oleh lingkungannya.

Hal di atas menunjukkan bahwa penalaran matematis antara siswa dengan gaya kognitif Field Dependent berbeda dengan penalaran matematis siswa dengan gaya kognitif Field Independent. Hal tersebut sesuai dengan penelitian yang dilakukan Devy Eganinta Tarigan (2012) yang menunjukkan bahwa penalaran mempengaruhi kemampuan siswa dalam memecahkan masalah. Kemudian lebih jauh dapat dilihat bahwa penalaran matematis siswa Field Independent lebih baik daripada siswa Field Dependent. Hal tersebut didukung penelitian oleh Saracho (1998) yang menyatakan bahwa seorang siswa dengan gaya kognitif analitik (FI) kemungkinan lebih berhasil dalam pelajaran yang membutuhkan kemampuan analitis dibandingkan siswa dengan gaya kognitif global (FD) dalam pelajaran yang sama.

Ditambahkan oleh penelitian Onyekuru (2015) yang menjelaskan bahwa siswa dengan gaya kognitif FI lebih unggul dalam prestasi sains dibandingkan siswa dengan gaya kognitif FD. Sedangkan siswa dengan gaya kognitif FD lebih unggul dalam prestasi seni dibandingkan siswa dengan gaya kognitif FI.

\section{KESIMPULAN DAN SARAN}

Berdasarkan hasil penelitian dan pembahasan, maka diperoleh kesimpulan bahwa penalaran matematis subjek dengan gaya kognitif Field Dependent dalam pemecahan masalah aljabar yaitu mampu mengidentifikasi masalah dengan menuliskan informasi yang diperoleh dari soal dengan jelas dan lengkap, mampu menggambarkan kondisi dari masalah dengan menggunakan gambar secara jelas dan lengkap serta memahami dengan baik maksud dari soal tersebut, dan mampu menghubungkan elemen-elemen yang berbeda dari informasi yang diperoleh dengan menggunakan bentuk aljabar namun belum sempurna.

Sedangkan penalaran matematis subjek dengan gaya kognitif Field Independent dalam pemecahan masalah aljabar yaitu mampu mengidentifikasi masalah dengan menuliskan informasi yang diperoleh dari soal dengan jelas dan lengkap, mampu menggambarkan kondisi dari masalah dengan menggunakan gambar secara jelas dan 
lengkap serta memahami dengan baik maksud dari soal tersebut, mampu menghubungkan elemen-elemen yang berbeda dari informasi yang diperoleh dengan menggunakan bentuk aljabar yang tepat, mampu menerapkan konsep aljabar yang telah dipelajari sebelumnya untuk membuat pengetahuan baru yang berguna dalam pencapaian solusi, dan mampu mengajukan dugaan strategi pemecahan masalah namun belum lengkap. Temuan pada penelitian ini adalah bahwa pada siswa Field Independent dengan skor tinggi, selain mampu memenuhi kelima indikator yang disebutkan di atas, subjek juga mampu memenuhi indikator penalaran matematis lainnya yaitu mampu menguji dugaan sesuai dengan strategi pemecahan masalah yang telah disusun dengan tepat dan menggunakan hubungan-hubungan yang telah dibuat untuk mencapai solusi, mampu menyusun bukti terhadap solusi yang diperoleh dengan menuliskan proses perhitungan secara sistematis, lengkap, dan jelas sehingga menghasilkan solusi yang tepat, mampu memberikan alasan logis terhadap solusi yang diperoleh, dan mampu menarik kesimpulan dengan tepat.

Saran yang diberikan agar kegiatan pembelajaran matematika berjalan dengan efektif dan agar penalaran matematis siswa dalam pembelajaran matematika dapat meningkat, diharapkan guru dapat memberikan perhatian lebih terhadap gaya kognitif siswa. Salah satu cara yang dapat digunakan adalah dengan mendesain metode pembelajaran yang berpusat pada siswa (student centered approach). Setelah mengetahui gaya kognitif yang dimiliki siswa, selanjutnya guru dapat menyesuaikan gaya mengajar dan memberi bimbingan terlebih pada siswa dengan gaya kognitif Field Dependent. Saran lain bagi guru untuk meningkatkan kemampuan penalaran matematis siswa adalah dengan memberikan masalah-masalah yang menantang dan mengembangkan penalaran matematis pada setiap kegiatan pembelajaran. Saran bagi peneliti lain, (1) diharapkan dapat melakukan penelitian lebih lanjut mengenai penalaran matematis dalam pemecahan masalah matematika yang lain (2) dapat dilakukan penelitian lebih lanjut mengenai hubungan antara penalaran matematis dengan aspek terkait lain, dan (3) dapat dilakukan penelitian lebih lanjut untuk membuat level-level penalaran matematis dalam pemecahan masalah.

\section{DAFTAR PUSTAKA}

Alamolhodaei, H. 2002. Student's Cognitive Style and Mathematical Word Problem Solving. Journal of the Korea Society of Mathematical Education Series D: Research in Mathematical Education. Vol. 6, No. 2, pp. 171-182.

Amrina Rista, Zulkardi, dan Yusuf Hartono. 2013. Pengembangan Soal Penalaran Model TIMSS SMP. Jurnal Kreano. Vol. 4, No. 1, hlm. 80-87. 
Aris Yuwono. 2010. Profil Siswa SMA dalam Memecahkan Masalah Matematika Ditinjau dari Tipe Kepribadian. Tesis. Program Pascasarjana UNS. Surakarta. (Unpublished).

Bilgin, I. and Karakirik, E. 2005. A Computer Based Problem Solving Environment in Chemistry. The Turkish Online Journal of Educational Technology. Vol. 4, No. 3, pp. 7-11

Desmita. 2011. Psikologi Perkembangan Peserta Didik. Bandung: PT. Remaja Rosdakarya.

Devy Eganita Tarigan. 2013. Analisis Kemampuan Pemecahan Masalah Matematika Berdasarkan Langkah-Langkah Polya ditinjau dari Kemampuan Penalaran Siswa. Tesis, Universitas Sebelas Maret Surakarta. (Unpublished).

Dimyati Mahmud. 2009. Psikologi Pendidikan Suatu Pendidikan Terapan. Yogyakarta: BPFE.

English, L. D. 2004. Mathematical and Analogical Reasoning of Young Learners. New Jersey: Lawrence. Erl Baum Associates.

Hamzah Uno. 2010. Orientasi Baru dalam Psikologi Pembelajaran. Jakarta: Bumi Aksara.

Lee, L., and Wheeler, D. 1989. The Arithmetic Connection. Educational Studies in Mathematics, Vol. 20, No. 1, pp. 41-54.

Loong, E., Vale, C., Bragg, L., and Herbert, S. 2014. Primary School Teacher's Perceptions of Mathematical Reasoning. Proceedings of the Thirty Seventh Annual Conference of the Mathematics Education Research Group of Australasia (pp. 466-472). Melbourne: MERGA.

Mullis, I.V.S., and Martin, M.O. 2013. TIMSS 2015 Assessment Frameworks. Chestnut Hills: Boston College.

Nasution. 2000. Berbagai Pendekatan Dalam Proses Belajar Mengajar. Jakarta: PT Bumi Aksara.

NCTM. 2009. Focus in High School Mathematics Reasoning and Sense Making. Reston: VA.

Nunes, T., Bryant, P., Barros, R., and Sylva, K. 2012. The Relative Importance of Two different Mathematical Abilities to Mathematical Achievement. British Journal of Educational Psychology, Vol. 82, No. 1, pp. 136-156.

Nur Ghufron dan Rini Risnawati. 2012. Gaya Belajar Kajian Teoretik. Yogyakarta: Pustaka Pelajar.

O'Brien T.P., Butler, S.M., and Bernold L.E. 2001. Group Embedded Figures Test and Academic Achievement in Engineering Education. International Journal Engineering Ed. Vol. 17, No 1, pp: 89-92 
Onyekuru, B.U. 2015. Field Dependence-Field Independence Cognitive Style, Gender, Career Choice and Academic Achievement of Secondary School Students in Emohua Local Government Area of Rivers State. Journal of Education and Practice. Vol. 6, No. 10, pp. 76-85

Panah, A. H. 2010. Study and Investigation of the Problem and Learning Disorders of Student by Various Cognitive Style in Mathematics Course at Rasht Shahid Chamran Higher Education Center. The Journal of Mathematics and Computer Science. Vol. 1, No. 3, pp. 216-229

Pithers, R.T. 2002. Cognitive Learning Styles: A Review of Field DependentIndependent Approach. Journal of Vocational Education and Raining. Vol. 13, No. 4, pp: 267-279

Rosnawati. 2013. Kemampuan Penalaran Matematika Siswa SMP Indonesia Pada TIMSS 2011. Prosiding Seminar Nasional Penelitian, Pendidikan dan Penerapan MIPA, Fakultas MIPA. Universitas Negeri Yogyakarta 18 Mei 2013.

Samo, M.A. 2009. Student's perceptions about symbols, letters and signs in algebra and how these affect their learning of algebra: A case study in a government girls' secondary school Karachi. Thesis. Pakistan: Aga Khan University.

Saracho, O.N. 1998. Editor's Introduction Cognitive Styles Research and Its Relationship to Various Disciplines. International Journal of Educational Research 29. pp: 169-172.

Sugiyono. 2013. Metode Penelitian Pendidikan (Pendekatan kuantitatif, kualitatif, dan $R \& D)$. Bandung: ALFABETA.

Sulistiawati. 2014. Analisis Kesulitan Belajar Kemampuan Penalaran Matematis Siswa SMP pada Materi Luas Permukaan dan Volume Limas. Makalah disajikan dalam Seminar Nasional Pendidikan Matematika, Sains, dan TIK di STKIP Surya: 15 Februari 2014.

Witkin H.A., and Goodenough D.R. 1976. Field Dependence and Interpersonal Behavior. (RB 76-12). Princeton: Educational Testing Service.

Witkin H.A., Moore, C.A., Goodenough D.R., and Cox, P.W. 1977. Field Dependent and Field Independent Cognitive Styles and Their Educational Implications. Review of Educational Research Winter 1977. Vol. 47, No. 1, pp. 1-64. 